\title{
TWO-DECADE REMAINING EFFECTS OF BAUXITE TAILINGS ON THE FISH TAXONOMIC STRUCTURE OF A CLEAR-WATER FLOODPLAIN LAKE IN CENTRAL AMAZON (BATATALAKE, PARÁ STATE, BRAZIL)
}

\author{
Bruno Eleres Soares ${ }^{*}$, Gisela Lefebvre Cabral², \\ Fernanda Estrella ${ }^{1} \&$ Érica Pellegrini Caramaschi ${ }^{1}$
}

\begin{abstract}
${ }^{1}$ Universidade Federal do Rio de Janeiro (UFRJ), Centro de Ciências da Saúde, Instituto de Biologia, Programa de Pós-Graduação em Ecologia. Av. Carlos Chagas Filho, 373, Ilha do Fundão, Rio de Janeiro, RJ, Brasil. CEP: 21941-902

${ }^{2}$ Senckenberg Research Institute and Natural History Museum Frankfurt, Department of River Ecology and Conservation. Clamecystrasse, 12, Gelnhausen, Germany. CEP: 63571

E-mails: soares.e.bruno@gmail.com,gisacabral@yahoo.com.br,fefeestrella@gmail.com,erica.caramaschi@gmail.com
\end{abstract}

\begin{abstract}
In recent decades, anthropic disturbances have led to major changes in biological communities. Batata Lake (Oriximiná, Pará State, Brazil) is located in the flood area of the right bank of Trombetas River and received effluents rich in mineral waste due to near mining activities in the 80 's, which led to the siltation of $30 \%$ of its area and numerous local impacts. We monitored about to 20 years the ichthyofauna of Batata Lake and we assessed if there is still remaining effects of the siltation by bauxite tailings in the affected area. We sampled in Silted and Non-Silted areas in the filling period of 1991 to 2015, using a set of gillnets with mesh sizes between 15 to $70 \mathrm{~mm}$. Differences in taxonomic structure (estimated richness, Simpson's dominance and Shannon's diversity) and in community composition among Silted and Non-Silted areas were evaluated with multivariate analysis, considering year as covariate. We sampled 10,435 individuals classified in 141 species. Only 41 species represented $90 \%$ of total abundance, which we considered the numerically dominant fishes in the lake. Among taxonomic indices, only estimated richness exhibited a significant trend through time; high estimated richness in the Silted area during the first years of monitoring and posterior decreasing. This negative slope was highly affected by a single point in 1992, so we considered it a particular case in time and not a real temporal trend. Significant changes in community composition occurred among areas by differentiation in species abundance, and not by species loss. These results show that siltation effects in Batata Lake did not express itself as a loss of biodiversity, but in the reconfiguration of the community composition according to species niche.
\end{abstract}

Keywords: fish assemblage; ichthyofauna; long-term monitoring; mining activities; siltation.

\section{INTRODUCTION}

Anthropogenic modification undoubtedly affects chemical parameters and habitat characteristics of aquatic systems, which alters environmental filters and thus local communities. Environmental filter is one of the predominant assumptions in several ecological studies in community scale, once it highlights species niche suitability to environment (Lebrija-Trejos et al. 2010). Despite other processes underlying community structure, the primordial role of environment in selecting species that can sustain viable populations and/or favor higher abundances of some species is the core of these studies.

In Neotropical fish communities, physicochemical parameters variability through seasonal or spatial gradients are often associated with changes in fish richness and composition (Ferreira \&
Casatti 2006, Súarez et al. 2011), as well as habitat characteristics in different scales (Galacatos et al. 2004). Nonetheless, habitat alterations, as expected by an environmental filtering assumption, also led to numerous changes in both local and regional scales. Specifically in lakes, a variety of causes has been pointed to change habitats and communities: transhumance, the summer transferring of the livestock to highlands in European Alps, alters the trophic state of lakes near highly pressured pastures (Tiberti et al. 2014); tourism causes pollution and contamination (Dokulil 2014); mining activities that deposited tailings in lakes led to siltation and/or heightening of metal concentrations, affecting local biodiversity (Bozelli et al. 2000, Klaverkamp et al. 2002, McDonald et al. 2010). Mining activities have also been showed to cause loss in the diversity of primary producers (Niyogi et 
al. 2002), loss of biomass of fishes and homogenization of fish fauna (Brosse et al. 2011, Hitt \& Chambers 2014) in lotic environments.

A unique monitored case of mining effects in Brazilian Amazon occurs in the Batata Lake, located on the right bank of Trombetas River, Pará, Brazil. The lake received effluents rich on inactive mineral waste between 1979 and 1989 from bauxite exploration by Mineração Rio do Norte (MRN). Bauxite tailings silted $30 \%$ of total area of the lake and caused numerous local impacts, such as the death of the Igapó Forest and the increase of the water turbidity in the Silted area (Bozelli et al. 2000). In the impacted area, the benthic macroinvertebrate communities exhibited a drastic change in composition: a loss in diversity and abundance of Dipteran larvae (Callisto \& Esteves 1996), oligochaetes and bivalves (Fonseca \& Esteves 1999), while the Ephemeropteran nymphaea of Campsurus notatus (Needham \& Murphey 1942) were well adapted to the siltation and exhibited higher densities and biomass in the Silted area (Leal \& Esteves 2000).

Caramaschi et al. (2000) analyzed ten years of fish monitoring and observed evidences of recovery of the Silted area based on diversity and biomass, but Lin (2003) still found lower abundance and biomass of fishes in the Silted area, which could be mediated by seasonal variation. Nevertheless, these studies did not evaluate the whole monitoring data to assess long-term impacts of the siltation in the fish fauna or the effects of the restoration of the Igapó in the Silted area. Thus, we analyzed almost 25 years (1991-2015) of monitoring of Batata Lake to assess if: (i) there was significant changes in estimated richness, dominance and diversity of the fish assemblage between areas; (ii) there was a temporal trend in the diversity indices in the Silted area; (iii) the community composition exhibits differences among both areas.

\section{MATERIAL AND METHODS}

\section{Study area}

Batata Lake is located in the flood area of the right bank of the Trombetas River, between coordinates $1^{\circ} 25^{\prime}$ and $1^{\circ} 35^{\prime} \mathrm{S}$, and $56^{\circ} 15^{\prime}$ ' and 56 $6^{\circ} 25^{\prime} \mathrm{W}$ (Figure 1 ), near Porto Trombetas, Oriximiná Municipality, Pará State, Brazil. The lake has clear water and vegetation predominantly of Igapó, it covers about $18 \mathrm{~km}^{2}$ during dry season and $30 \mathrm{~km}^{2}$ in rainy season and it is continuously connected to Trombetas River through its southern portion (Panosso 2000).

\section{Caption}
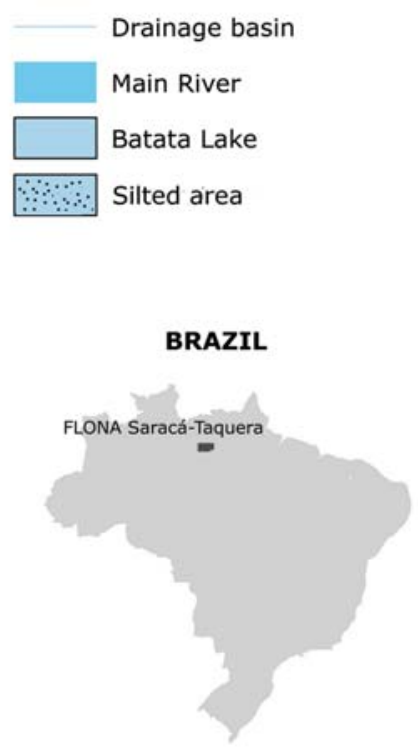

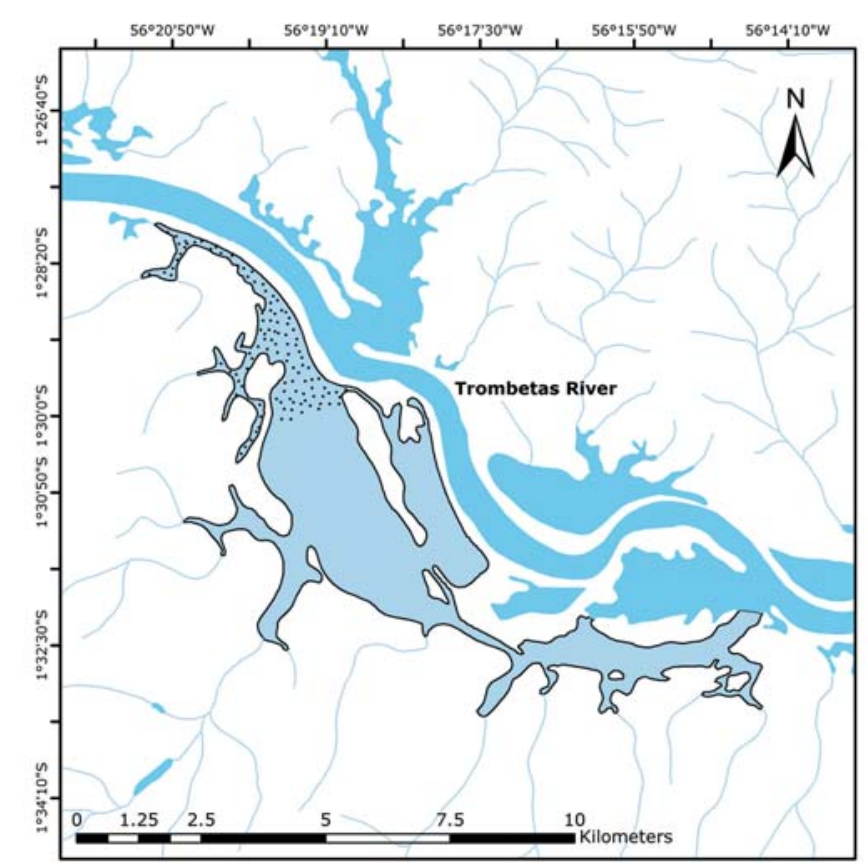

Geographic Coordinate System \& Datum: WGS84 Source: MRN \& MMA Elaboration: Fernanda Estrell

Figure 1. Batata Lake, Oriximiná Municipality, Pará State, Brazil. The National Forest Saracá-Taquera and the Trombetas River are highlighted, as well as the Silted area of the lake (dotted). 
Due to mining activity in the National Forest Saracá-Taquera, a situation of spatial heterogeneity within the lake was built: a Silted area and a NonSilted area. Even ten years later the stoppage of mineral waste emission, the Silted area still exhibited lower transparency and depth than the Non-silted area (Lin \& Caramaschi 2005a).

\section{Sampling design}

Standardized sampling was carried out between 1991 and 2015 (except 1994-1996) during the filling period, usually on March. Fishes were caught using a set of gillnets with mesh sizes between 15 to $70 \mathrm{~mm}$, setup among 04:00 pm and 06:00 pm, inspected and winkled out from 08:00 pm; resettlement at 03:30 am, inspected and removed from 08:00 am. Samplings occurred in two different areas of the lake: (i) the Silted area, which exhibits bauxite tailings located on the portion of the lake affected by siltation where the natural substrate of the lake is completely covered; (ii) and the NonSilted area, with no evidence of bauxite tailings. Through the years, sampling occurred in different nearby points in each area.

Individuals were identified as morphotypes on field, fixed with formalin $10 \%$, individually labeled and sent to determination on the Fish Ecology Laboratory at the Federal University of Rio de Janeiro (UFRJ). Voucher specimens were deposited in the collection of the Fish Ecology Laboratory/ UFRJ (Appendix 1). Sampling methods were designed in the beginning of the monitoring (1990) and were maintained in order to grant the temporal analyses of the fish community, being described in detail by Caramaschi et al. (2000).

\section{Data analysis}

We analyzed differences on the taxonomic diversity and on the ichthyofauna composition among Silted and Non-Silted areas in Batata Lake. Only dominant fish species were considered for the analyses; dominant species were considered as the most abundant species in Batata Lake that summed up 90\% of total abundance caught over the years.
As multiple factors interact in diversity structuring, we considered that the long time series could explain partially the diversity changes observed in our dataset. This could happen for two reasons: (i) temporal turnover is a ubiquitous phenomenon in natural communities that would lead to higher similarity the nearer in time samples are; (ii) the lake did not receive bauxite waste after the 90's and the Silted area partially recovered its Igapó Forest through the years, which would affect fish diversity. So, all of our analyses aimed to consider the effect of temporal changes in fish diversity.

We calculated three indices to evaluate different properties of the taxonomic diversity: (i) Jackknife 1 (estimated richness); (ii) Simpson's index (dominance); and (iii) Shannon's diversity. We used paired t-tests to analyze if there are differences between Silted and Non-silted areas for each index.

In order to evaluate if there was trends in the taxonomic indices in the Silted area through time, we calculated a ratio for each index between Silted and the Non-Silted area values in the same year. The higher the ratio value, the higher the index (richness, dominance or diversity) in the Silted area. We used a linear regression to evaluate if there are temporal trends in the ratios and, consequently, restoration to similar taxonomic structures. Thus, if there was a difference in the earlier years between areas (e.g., lower richness in the Silted area) but not in the next years, an increasing trend in the richness ratio would be observed.

We also evaluated if fish composition varied among Silted and Non-Silted areas using an Analysis of Similarity (ANOSIM) of two factors. We used area as the first factor and a factor with five categories that include 5-years blocks (Period 1: 1991-1995; Period 2: 1996-2000; Period 3: 2001-2005; Period 4: 2006-2010; Period 5: 2011-2015). Herein, we report only the effect of the Area controlled by time variation on community composition. Afterwards, we used a Similarity Percentages analysis (SIMPER) to observe which species were determinants in the differences in the fish assemblage among areas.

We used the vegan package (Oksanen et al. 2016) to calculate diversity indices and analyses related to community composition in R (R Core Team 2016). All statistical tests considered 5\% significance level. 


\section{RESULTS}

\section{Taxonomic diversity}

We sampled 10,435 individuals identified in 141 species. Forty-one species, classified in five orders and 16 families, represented $90 \%$ of total abundance $(9,412)$. Characiformes was the most abundant order (53.79\% of total abundance), but the siluriform family Auchenipteridae was the most abundant family (27.45\%), followed by Hemiodontidae (18.38\%) and Curimatidae (12.15\%). The most abundant species was Auchenipterichthys longimanus (Günther, 1864), which represented $22.4 \%$ of the most abundant species. The remaining most abundant species were Curimata vittata (Kner, 1858) (7.5\% of total abundance), Triportheus albus Cope, 1872 (6\%) and Hemiodus argenteus Pellegrin, 1909 (6\%). The most abundant species that summed up $90 \%$ of total abundance in Batata lake were considered dominant (Figure 2a) and were used in subsequent analyses. Differences in species abundance between areas may be seen in Figures $2 \mathrm{~b}$ and 2c.

Estimated richness ranged from 20 to 61 (36 \pm 8). Richness did not exhibited differences among Silted and Non-Silted areas (Figure 3a; $\mathrm{t}=1.65$; $\mathrm{df}=$ $19 ; \mathrm{p}=0.11$ ), but we observed a negative temporal trend (Figure $3 b ; \mathrm{R}^{2}=0.20 ; \mathrm{p}=0.03$ ); that is, richness was higher in the Silted area that in the non-Silted area in the first years (high Silted/Non-Silted ratio) and decreased after it. Although a linear regression was significant, we observe that this is not a steady trend; the high Silted/non-Silted ratio in the first years is represented by a single year (1992) that seems to be an outlier in the expected richness' temporal pattern (Figure 3b). When we exclude 1992 from the analysis, there is no temporal trend left $\left(\mathrm{R}^{2}=0.05\right.$; $\mathrm{P}$ $=0.19$ ). Simpson's index ranged from 0.62 to 0.94 $(0.85 \pm 0.07)$. Dominance did not exhibit any patterns among areas (Figure 3c; $\mathrm{t}=0.31 ; \mathrm{df}=19 ; \mathrm{p}=0.76$ ) nor temporal patterns (Figure 3d; $\mathrm{R}^{2}=0.04 ; \mathrm{p}=0.38$ ). Shannon's diversity ranged from 1.89 to 3.30 (2.63 \pm 0.33 ) and also did not show spatial (Figure 3e; $t=$ $0.35 ; \mathrm{df}=19 ; \mathrm{p}=0.73$ ) or temporal (Figure $3 \mathrm{f} ; \mathrm{R}^{2}=$ $-0.05 ; \mathrm{p}=0.90)$ patterns.

\section{Community composition}

Ichthyofauna composition was slightly dissimilar among Silted and Non-Silted areas $(\mathrm{R}=0.26 ; \mathrm{p}<0.001)$ due to variance in species' abundance in the same year. Species displayed higher abundances in different areas (Table 1); Triportheus albus, Curimata vittata and Hemiodus argenteus were more abundant in the Silted area, whereas Hemiodus immaculatus Kner, 1858 was more abundant in the Non-Silted area, for example. Fourteen species summed half the dissimilarity among Silted and Non-Silted areas, which highlights that some species are more/less prone to occupy a specific area than others.

\section{DISCUSSION}

Batata Lake does not display consistent alterations in species' richness or dominance responding to the siltation. However, ichthyofauna composition differed among the two areas due to species occupancy pattern; some species were more abundant in the Silted area and other species were more abundant in the Non-Silted area. Caramaschi et al. (2000) already observed similar richness among areas in the first decade of monitoring, except by a heightening of the richness in the Silted area in the filling period due to the attraction of expanded areas provided by inundation, but this difference is not a temporal trend in Batata Lake. In addition, Lin \& Caramaschi (2005b) also did not observe differences in the fish diversity between the two areas in the first years of monitoring.

Mining does not exhibit a clear trend over taxonomic structure of fish communities; some areas display biodiversity loss (Kimmel \& Argent 2009, Melcher et al. 2012), but others do not (Brosse et al. 2011). Direct comparisons should not be made, since cases are submitted to different mining pressures and are distributed over different ecosystems. Bauxite tailings are chemically inactive and have a physical effect in the ecosystem, translated in a constant suspension and sedimentation process. Besides that, Batata Lake has a complex dynamic due to the annual variation in rainfall, which affects its size, as well as its connectivity with Trombetas River and the 
surrounding Igapó Forest. In the case of Batata Lake, the hydrological period we analyzed (filling period) comprises a season with a strong flooding pulse that diminishes the limnological effects of the tailings over the Silted area and also promotes weaker biological stress from siltation (Bozelli et al. 2009). Even with the attenuating effect of the filling period, the siltation provided distinct environmental filters in different areas. In general, it was registered a loss in the depth of the water column, higher turbidity, lower primary production and lower densities of benthic macroinvertebrate fauna (Table 2).

Fish communities may response to environmental changes caused by human impacts through changes in its functional structure and composition, primarily due to abundance responses to temporal and spatial variation (Winemiller et al. 2008). Indeed, Brosse et al. (2011) observed that stream fish communities have functional responses to mining activities, which favor smaller and habitat-generalist fishes over larger and habitat-specialist species. In Batata Lake, changes in ichthyofauna did not occur by species loss, but by small changes in species' abundance due to habitat preferences, as discussed below. The response based on differences in species' relative abundance may be caused by strong lateral movement of the fishes that inhabit the lake, which may also attenuate the differences between the two areas.

When it comes to fish composition, siluriforms were most abundant in the Silted area. Siluriforms are primarily nocturne and exhibit morphological adaptation to use turbid environments (Brejão et al. 2013), which partially explains their success in low-light environments in Amazon basin (Rodríguez \& Lewis 1997, Galacatos et al. 2004) and in the Silted area of Batata Lake (e.g., A. longimanus and Astrodoras asterifrons).

Curimata vittata, a detritivorous characiform, was more abundant in the Silted area of Batata Lake, which can be a consequence of the ecosystem role of the highly dominant ephemeropteran C. notatus in the Silted area through bioturbation. C. notatus nymphs build burrows up to $13 \mathrm{~cm}$ that allow water flow within it, which expanded the aerobic layer that led to higher bacterial production in the in the Silted area (Leal et al. 2003, 2005). The expansion of the bacterial production within the sediment of the Silted area can enhance decomposition process
(Santana et al. 2015), which would favor the occurrence of $C$. vittata in the Silted area.

Hemiodontids did not exhibit a clear trend: some hemiodontids were more abundant in the Silted area and $H$. immaculatus was more abundant in the NonSilted area. Species that used primarily the Silted area exhibited a tendency to herbivory, using predominantly algae, while $H$. immaculatus consumes predominantly autochthonous invertebrates (M. F. O. Pinto, unpublished data). These patterns are in accordance with benthonic macroinvertebrates, which exhibit lower densities in the Silted area (Callisto 2000), and also with the greater amount of algae in the substrate due to algal sinking from algae-clay aggregation (Guenther \& Bozelli 2004) or with the greater algae development on detritus due to low depths that allow the euphotic zone to reach the bottom of the lake in the Silted area, as suggested by Lin \& Caramaschi (2005b). Thus, the distribution of Hemiodontids within the lake seems related to the spatial distribution of their food items (aquatic macroinvertebrates and algae) in response to siltation.

Piscivorous species also did not exhibit a clear trend of habitat occupancy toward Silted or Non-Silted area in Batata Lake. Given that, the higher turbidity in the Silted area during the filling period must not be a crucial factor in their distribution within the lake. As suggested by Lin \& Caramaschi (2005b), the turbidity in the filling period may not have reached critical levels to inhibit these species occurrence. The habitat preferences of these species may be related to depth preferences, as shown by Layman \& Winemiller (2005); pirañas from the genus Serrasalmus and peacock basses (Cichla) are more abundant in deep waters, while the spotted pike-characin (Boulengerella) used predominantly sand banks.

Therefore, the bauxite waste impact in Batata Lake did not express itself in the loss of fish richness, but in the same way that happened for the invertebrate fauna: in a reconfiguration of the community structure. These changes in fauna composition are one of the main patterns of current defaunation worldwide, and may have consequences for both ecosystem functioning and evolutionary processes (Dirzo et al. 2014). This looks even more concerning when composition changes in response to anthropic impacts persist through time, as it happen in Batata Lake. 

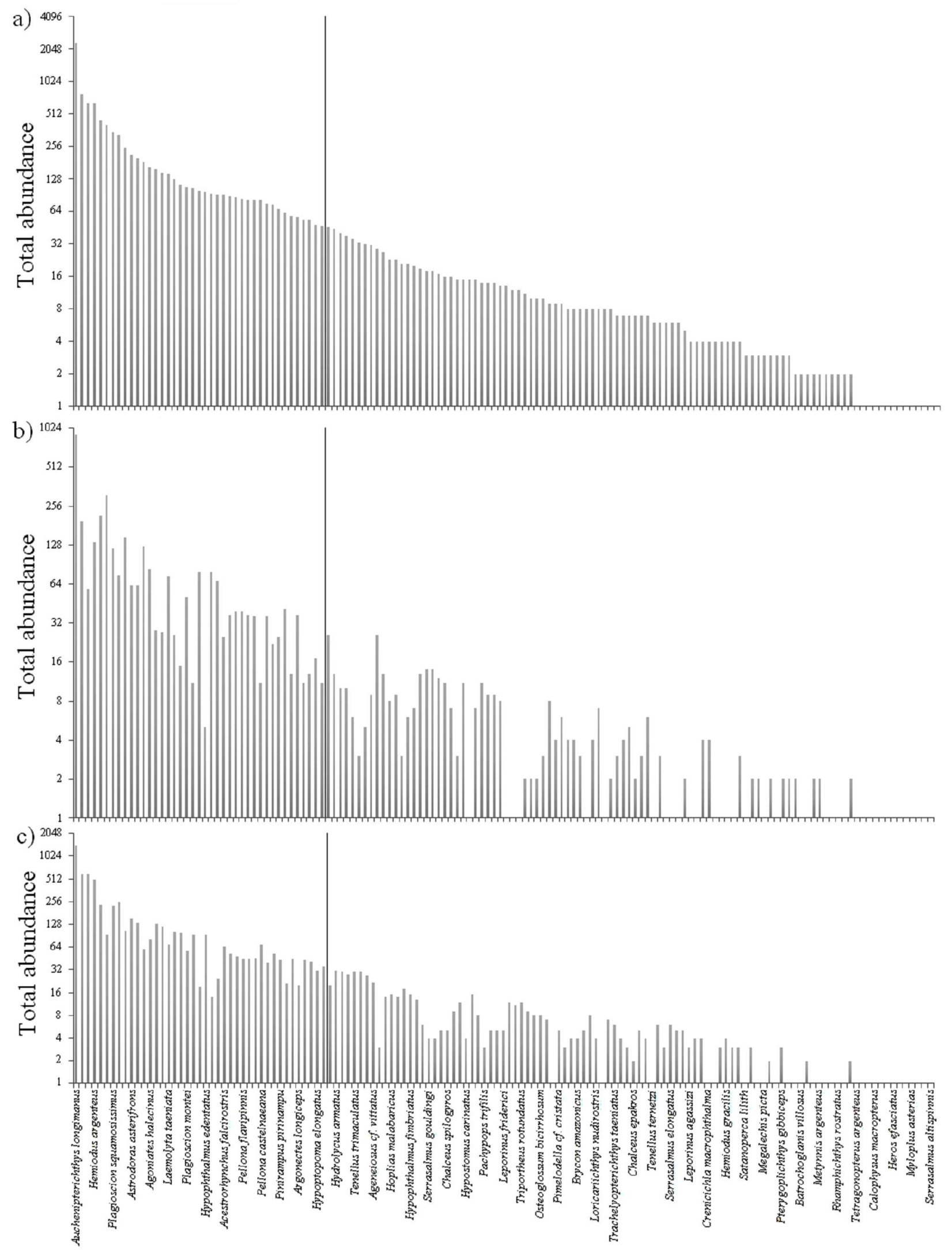

Species

Figure 2. Total abundance of all species captured in all lake (a), only in the Non-Silted area (b) and only in the Non-Silted area (c) of Batata Lake, Pará State, Brazil. Y axes are shown in logarithmic scale. Dominant species are in the left of the black lines. 
a)

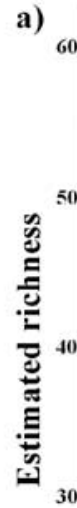

20

c)

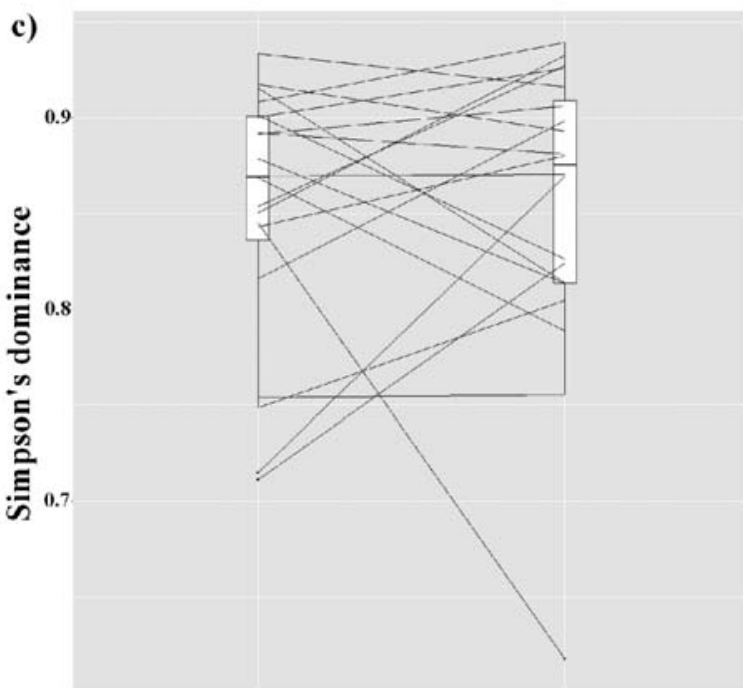

e)

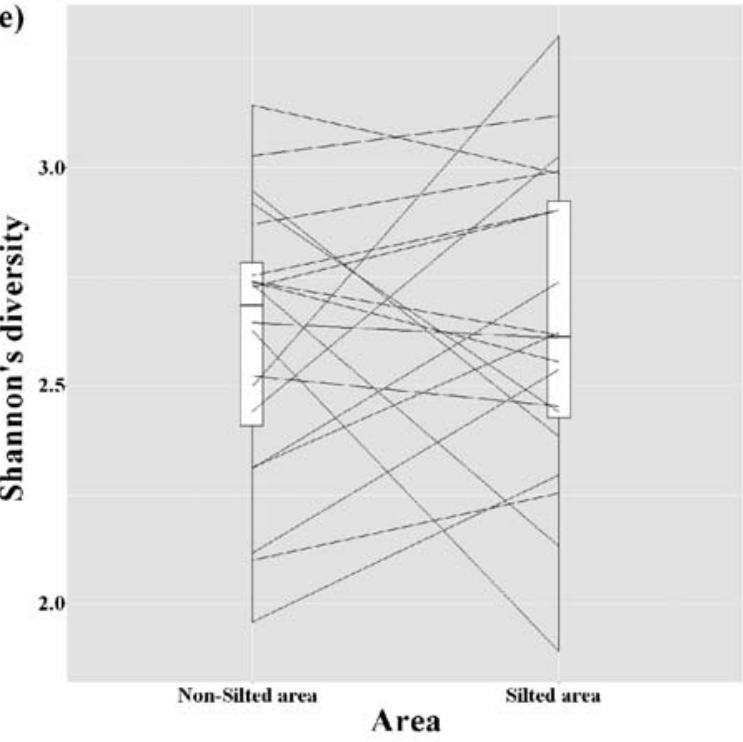

b)

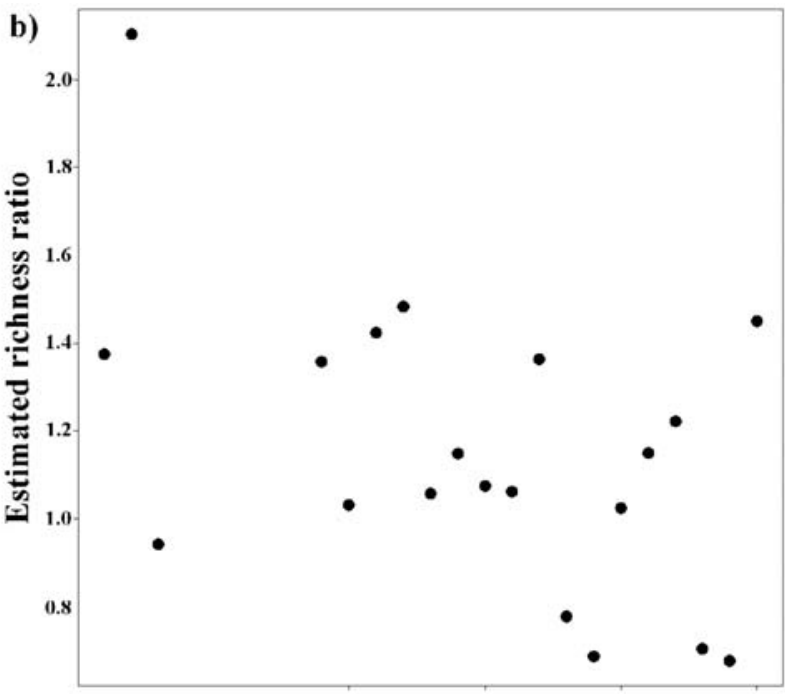

d)

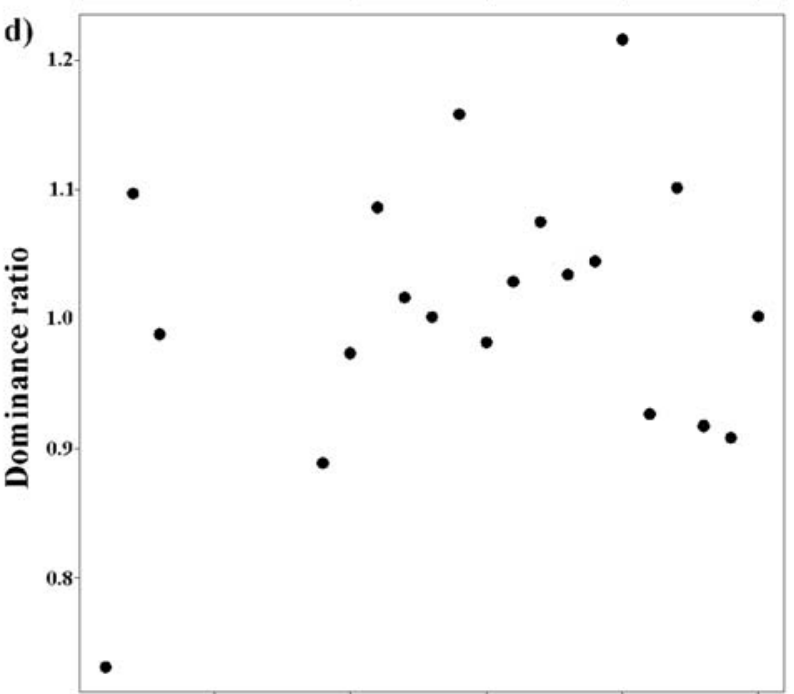

f)

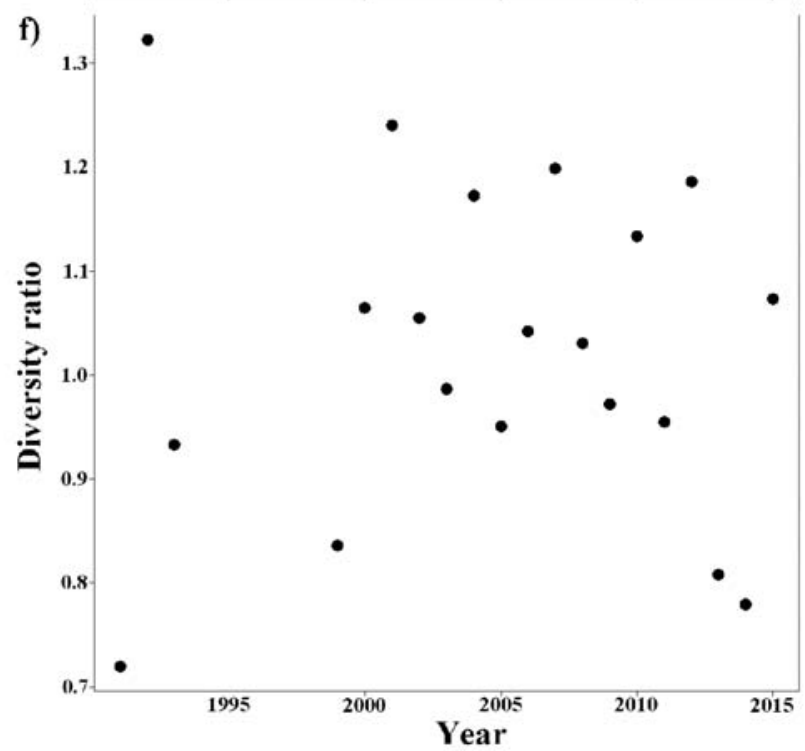

Figure 3. Profile plots comparing estimated richness (a), Simpson’s dominance (c) and Shannon's diversity (e) of Silted and NonSilted areas in the same year, and the temporal pattern of the ratio between Silted and Non-Silted area of estimated richness (b), Simpson’s dominance (d) and Shannon's diversity (e) for the fish community sampled between 1991 and 2015 in Batata Lake, Pará State, Brazil. Lines in the profile plots refer to samples within same year, and profile plots show median, standard error and minimum and maximum values. 
Table 1. Main species that contributed to the dissimilarity among Silted and Non-silted areas in Batata Lake, Pará State, Brazil, displayed by SIMPER analysis. We show the mean square-rooted abundance for each area (Abundance), the contribution of each species to total dissimilarity among areas (Contrib.), and the total contribution of shown species to total dissimilarity (Total Contrib.).

\begin{tabular}{lccc}
\hline \multicolumn{1}{c}{ Species } & \multicolumn{2}{c}{ Abundance } & \\
\cline { 2 - 3 } & Silted & Non-Silted & Contrib. (\%) \\
\cline { 2 - 3 } Triportheus albus & 4.23 & 0.98 & 5.76 \\
Curimata vittata & 4.03 & 2.22 & 5.70 \\
Hemiodus argenteus & 4.15 & 2.04 & 4.77 \\
Auchenipterichthys longimanus & 7.57 & 6.56 & 4.42 \\
Hemiodus immaculatus & 1.38 & 2.71 & 3.92 \\
Hemiodus unimaculatus & 2.77 & 2.49 & 3.70 \\
Acestrorhynchus microlepis & 3.01 & 1.57 & 3.30 \\
Bryconops alburnoides & 1.54 & 2.17 & 3.16 \\
Micromischodus sugillatus & 0.94 & 1.61 & 2.91 \\
Hypophthalmus marginatus & 1.81 & 0.63 & 2.70 \\
Agoniates halecinus & 0.88 & 1.21 & 2.70 \\
Plagioscion squamosissimus & 2.79 & 2.16 & 2.59 \\
Boulengerella lucius & 1.54 & 0.40 & 2.47 \\
Astrodoras asterifrons & 2.07 & 1.58 & 2.46 \\
\hline Total Contrib. (\%) & & & 50.56 \\
\hline
\end{tabular}

Table 2. Main environmental differences between Silted and Non-Silted areas in Batata Lake, Pará State, Brazil, in early years after waste release (1988-1992), summarized from Bozelli et al. (2000).

\begin{tabular}{|c|c|c|}
\hline Environmental factor & Values (Silted vs. Non-Silted) & References \\
\hline $\begin{array}{l}\text { Higher turbidity in the } \\
\text { Silted area }\end{array}$ & $\begin{array}{l}\text { Water transparency by Secchi disk between } \\
1988 \text { and } 1992-0.9 \text { vs. } 1.65 \mathrm{~m}\end{array}$ & Panosso \& Kubrusly (2000) \\
\hline $\begin{array}{l}\text { Lower depth of water } \\
\text { column in the Silted area }\end{array}$ & $\begin{array}{l}\text { Depth of water column between } 1988 \text { and } \\
1992-3.08 v s .6 .20 \mathrm{~m}\end{array}$ & Panosso \& Kubrusly (2000) \\
\hline \multirow[b]{2}{*}{$\begin{array}{l}\text { Lower primary production } \\
\text { in the Silted area }\end{array}$} & $\begin{array}{l}\text { Maximum phytoplankton primary production } \\
\text { in } 1989-188 \mathrm{vs} .260 \mathrm{mgCm}^{-3} \mathrm{~d}^{-1}\end{array}$ & Roland (2000) \\
\hline & $\begin{array}{l}\text { Net primary productivity obtained } \\
\text { experimentally in control and silted samples } \\
\left(10-20 \mathrm{mg}^{-1} \text { of bauxite waste concentration) }\right. \\
-<20 \mathrm{vs} .>80 \mathrm{mgCm}^{3} \mathrm{~h}^{-1}\end{array}$ & Roland (2000) \\
\hline $\begin{array}{l}\text { Lower density of benthic } \\
\text { macroinvertebrates in the } \\
\text { Silted area }\end{array}$ & $\begin{array}{l}\text { Total density in } 1992-\approx 110 v s . \approx 500 \\
\text { ind. } \mathrm{m}^{-2}\end{array}$ & Bozelli (2000) \\
\hline
\end{tabular}




\section{ACKNOWLEDGEMENTS}

We are grateful to Dr. Francisco A. Esteves, Dr. Fábio Roland and Dr. Reinaldo L. Bozelli for the invitation to participate in the monitoring of Batata Lake. We are also grateful to Mineração Rio do Norte (MRN) by the financial support. CNPq and CAPEs granted scholarships to the authors (BES, GLC and FE). We thank to Alberto Akama and an anonymous referee for comments that improved the previous version of the manuscript. Numerous researchers collaborated to the monitoring through the last two decades, and they were essential during fieldwork and specimens' identification.

\section{REFERENCES}

Bozelli, R. L. 2000. Zooplâncton. In: R. Bozelli, F. A. Esteves \& F. Roland (Eds.), Lago Batata: impacto e recuperação de um ecossistema amazônico. pp. 119-138. Rio de Janeiro: IBUFRJ/Sociedade Brasileira de Limnologia.

Bozelli, R. L., Esteves, F. A., \& Roland, F. (Eds.). 2000. Lago Batata: Impacto e recuperação de um ecossistema amazônico. Rio de Janeiro: IB-UFRJ/Sociedade Brasileira de Limnologia: p. 346.

Bozelli, R. L., Caliman, A., Guariento, R. D., Carneiro, L. S., Santangelo, J. M., Figueiredo-Barros, M. P., Leal, J. F. J., Rocha, A. M., Quesado, L. B., Lopes, P. M., Farjalla, V. F., Marinho, C. C., Roland, F., Esteves, F. A. 2009. Interactive effects of environmental variability and human impacts on the long-term dynamics of an Amazonian floodplain lake and a South Atlantic coastal lagoon. Limnologica - Ecology and Management of Inland Waters, 39(4), 306-313. DOI: 10.1016/j.limno.2009.06.004

Brejão, G. L., Gerhard, P., \& Zuanon, J. 2013. Functional trophic composition of the ichthyofauna of forest streams in eastern Brazilian Amazon. Neotropical Ichthyology, 11(2), 361-373. DOI: $10.1590 / \mathrm{S} 1679-62252013005000006$

Brosse, S., Grenouillet, G., Grevey, M., Khazraie, K., Tudesque, L. 2011. Small-scale gold mining erodes fish assemblage structure in small neotropical streams. Biodiversity and Conservation, 20(5), 1013-1026. DOI: 10.1007/s10531-011-0011-6

Callisto, M., \& Esteves, F. A. 1996. Macroinvertebrados bentônicos em dois lagos amazônicos: Lago Batata (um ecossistema impactado por rejeito de bauxita) e Lago Mussurá (Brasil). Acta Limnologica Brasiliensia, 8(1), 137-147.

Callisto, M. 2000. Macroinvertebrados Bentônicos. In: R. Bozelli, F. A. Esteves \& F. Roland (Eds.), Lago Batata: impacto e recuperação de um ecossistema amazônico. pp. 141-151. Rio de Janeiro: IB-UFRJ/Sociedade Brasileira de Limnologia.

Caramaschi, E. P., Halboth, D. A., \& Mannheimer, S. 2000. Ictiofauna. In: R. Bozelli, F. A. Esteves \& F. Roland, F. (Eds.), Lago Batata: impacto e recuperação de um ecossistema amazônico. pp. 153-177. Rio de Janeiro: IB-UFRJ/Sociedade Brasileira de Limnologia.

Dirzo, R., Young, H. S., Galetti, M., Ceballos, G., Isaac, N. J. B., Collen, B. 2014. Defaunation in Anthropocene. Science, 345(6195), 401-406. DOI: 10.1126/science. 1251817

Dokulil, M. T. 2014. Environmental impacts of tourism on lakes. In: A. A. Ansari \& S. S. Gill (Eds.), Eutrophication: causes, consequences and control. Pp. 81-88. The Netherlands: Springer.

Ferreira, C. P., \& Casatti, L. 2006. Integridade biótica de um córrego na bacia do Alto Rio Paraná avaliada por meio da comunidade de peixes. Biota Neotropica, 6(3), 1-25.

Fonseca, J. J. L., \& Esteves, F. A. 1999. Influence of bauxite tailings on the structure of the benthic macroinvertebrates community in an Amazonian lake (Lago Batata, Pará, Brazil). Revista Brasileira de Biologia, 59(3), 397-405.

Galacatos, K., Barriga-Salazar, R., \& Stewarts, D. J. 2004. Seasonal and habitat influences on fish communities within the lower Yasuni River basin of the Ecuadorian Amazon. Environmental Biology of Fishes, 71(1), 33-51. DOI: 10.1023/ B:EBFI.0000043156.69324.94

Guenther, M., \& Bozelli, R. 2004. Factors influencing algae-clay aggregation. Hydrobiologia, 523(1), 217-223. DOI: 10.1023/ B:HYDR.0000033127.05034.32

Hitt, N., \& Chambers, D. B. 2014. Temporal changes in taxonomic and functional diversity of fish assemblages downstream from mountaintop mining. Freshwater Science, 33(3), 915-926. DOI: $10.1086 / 676997$

Kimmel, W. G., \& Argent, D. G. 2009. Stream fish community responses to a gradient of specific conductance. Water, Air and Soil Pollution, 206(1), 49-56. DOI: 10.1007/s11270-009-0085-x

Klaverkamp, J.F., Baron, C.L., Fallis, B.W., Ranson, C.R., Wautier, K.G., Vanriel, P. 2002. Metals and metallothionein in fishes and metals in sediments from lakes impacted by uranium mining and milling in northern Saskatchewan. Canadian Technical Report of Fisheries and Aquatic Sciences 2420; p. 72. Winnipeg, Fisheries and Oceans Canada. Retrieved from http://www.dfo-mpo.gc.ca/Library/267553.pdf

Layman, C. A., \& Winemiller, K. O. 2005. Patterns of habitat segregation among large fishes in a Venezuelan floodplain river. Neotropical Ichthyology, 3(1), 111-117. DOI: 10.1590/S167962252005000100007

Leal, J. J. F., \& Esteves, F. A. 2000. Life cycle and production of Campsurus notatus (Ephemeroptera, Polymitarcyidae) in an Amazonian lake impacted by bauxite tailings (Pará, Brazil). Hydrobiologia, 437(1-3), 91-99. DOI: 10.1023/ A:1026526101039

Leal, J. J. F., Esteves, F. A., Farjalla, V. F., Enrich-Prast, A. 2003. Effect of Campsurus notatus on $\mathrm{NH} 4+$, DOC fluxes, $\mathrm{O}_{2}$ uptake and bacterioplankton production in experimental microcosms with sediment-water interface of an Amazonian lake impacted by bauxite tailings. International Review of Hydrobiology, 88(2), 167-178. DOI: 10.1002/iroh.200390012

Leal, J. J. F., Enrich-Prast, A., Esteves, F. A., Bozelli, R., Farjalla, V. F. 2005. Influence of Campsurus notatus bioturbation on oxygen profile and uptake in sediments of an Amazonian lake impacted by bauxite tailings. Archiv fur Hydrobiologie, 162(4), 557-574. DOI: 10.1127/0003-9136/2005/0162-0557

Lebrija-Trejos, E., Pérez-García, E. A., Meave, J. A., Bongers, F., Poorter, L. 2010. Functional traits and environmental filtering drive community assembly in a species-rich tropical system. Ecology, 91(2), 386-398. DOI: 10.1890/08-1449.1

Lin, D. S. C. 2003. Hábitat, pulso de inundação e assoreamento por rejeito de bauxita como fatores estruturadores da comunidade de peixes de um lago amazônico (Lago Batata, PA). Departamento de Ecologia da Universidade Federal do Rio de Janeiro. p. 171. 
Lin, D. S. C.. \& Caramaschi, E. P. 2005a. Seasonal and diel stability of limnological parameters and habitat structure in a floodplain lake silted by bauxite tailings (Lago Batata, Pará, Brazil). Amazoniana (Kiel), 18(3/4), 185-202.

Lin, D. S. C., \& Caramaschi, E. P. 2005b. Responses of the fish community to the flood pulse and siltation in a floodplain lake of the Trombetas River, Brazil. Hydrobiologia, 545(1), 75-91. DOI: 10.1007/s10750-005-2186-X

McDonald, C. P., Urban, N. R., Barkach, J. H., McCauley, D. 2010. Copper profiles in the sediments of a mining-impacted lake. Journal of Soils and Sediments, 10(3), 343-348. DOI: 10.1007/s11368-009-0171-0

Melcher, A. H., Ouedraogo, R., \& Schmutz, S. 2012. Spatial and seasonal fish community patterns in impacted and protected semi-arid rivers of Burkina Faso. Ecological Engineering, 48(1), 117-129. DOI: 10.1016/j.ecoleng.2011.07.012

Niyogi, D. K., Lewis-Jr., W. M., \& McKnight, D. M. 2002. Effects of stress from mine drainage on diversity, biomass, and function of primary producers in mountain streams. Ecosystems, 5(6), 554-567. DOI: 10.1007/s10021-002-0182-9

Oksanen, F., Blanchet, G., Kindt, R., Legendre, P., Minchin P. R., OöHara, R. B., Simpson, G. L., Solymos, P., Stevens M. H. H., Wagner H. 2016. vegan: Community Ecology Package. R package version 2.3-5.

Panosso, R., \& Kubrusly, L. 2000. Avaliação espacial e temporal das variáveis limnológicas básicas e nutrientes. In: R. Bozelli, F. A. Esteves \& F. Roland (Eds.) 2000, Lago Batata: Impacto e Recuperação de um Ecossistema Amazônico. pp. 55-71. Rio de Janeiro: IB-UFRJ/Sociedade Brasileira de Limnologia.

Panosso, R. 2000. Considerações geográficas e geomorfológicas. In: R. Bozelli, F. A. Esteves \& F. Roland (Eds.) 2000, Lago Batata:
Impacto e Recuperação de um Ecossistema Amazônico. pp. 3754. Rio de Janeiro: IB-UFRJ/Sociedade Brasileira de Limnologia. R Core Team. 2016. R: A language and environment for statistical computing. R Foundation for Statistical Computing, Vienna, Austria. URL: https://www.R-project.org/

Rodríguez, M. A., \& Lewis, W. M. 1997. Structure of fish assemblages along environmental gradients in floodplain lakes of the Orinoco River. Ecological Monographs, 67(1), 109-128.

Santana, A. R. A., Werth, M., \& Benedito-Cecilio, E. 2015. Use of food resources by detritivorous fish in floodplains: a synthesis. Acta Biológica Colombiana, 20(1), 5-14. DOI: 10.15446/abc.v20n1.42260

Roland, F. 2000. Produção primária fitoplanctônica. In: R. Bozelli, F. A. Esteves \& F. Roland (Eds.) 2000, Lago Batata: Impacto e Recuperação de um Ecossistema Amazônico. pp. 105-117. Rio de Janeiro: IB-UFRJ/Sociedade Brasileira de Limnologia. Súarez, Y. R., Souza, M. M., Ferreira, F. S., Pereira, M. J., Silva, E. A., Ximenes, L. Q. L., Azevedo, L. G., Martins, O. C., LimaJúnior, S. E. 2011. Patterns of species richness and composition of fish assemblages in streams of the Ivinhema River basin, Upper Paraná River. Acta Limnologica Brasiliensia, 23(2), 177188. DOI: $10.1590 / S 2179-975 X 2011000200008$

Tiberti, R., Rogora, M., Tartari, G., Callieri, C. 2014. Ecological impact of transhumance on the trophic state of alpine lakes in Gran Paradiso National Park. Knowledge and Management of Aquatic Ecosystems, 415(1), 1-17. DOI: 10.1051/kmae/ 2014030

Winemiller, K.O., López-Fernández, H., Taphorn, D.C., Nico, L.G., Duque, A. B. 2008. Fish assemblages of the Casiquiare River, a corridor and zoogeographic filter for dispersal between the Orinoco and Amazon basins. Journal of Biogeography, 35(9), 1551-1563. DOI: 10.1111/j.1365-2699.2008.01917. 
Appendix 1. List of species and respective voucher numbers of the 41 most dominant species in the Batata Lake, Pará, Brazil. Specimens were deposited in the ichthyological collection of the Fish Ecology Lab (DEPRJ) of the Federal University of Rio de Janeiro (UFRJ).

\begin{tabular}{|c|c|}
\hline Order/Family/Species & Voucher number \\
\hline \multicolumn{2}{|l|}{ Characiformes } \\
\hline \multicolumn{2}{|l|}{ Serrasalmidae } \\
\hline Myloplus lobatus (Valenciennes, 1850) & DEPRJ 8415 \\
\hline Serrasalmus rhombeus (Linnaeus, 1766) & DEPRJ 8334 \\
\hline \multicolumn{2}{|l|}{ Hemiodontidae } \\
\hline Argonectes longiceps (Kner, 1858) & DEPRJ 8337 \\
\hline Hemiodus argenteus Pellegrin, 1909 & DEPRJ 8407 \\
\hline Hemiodus immaculatus Kner, 1858 & DEPRJ 8340 \\
\hline Hemiodus unimaculatus (Bloch, 1794) & DEPRJ 8338 \\
\hline Micromischodus sugillatus Roberts, 1971 & DEPRJ 8414 \\
\hline \multicolumn{2}{|l|}{ Anostomidae } \\
\hline Laemolyta taeniata (Kner, 1858) & DEPRJ 8412 \\
\hline Leporinus fasciatus (Bloch, 1794) & DEPRJ 8413 \\
\hline \multicolumn{2}{|l|}{ Chilodontidae } \\
\hline Caenotropus labyrinthicus (Kner, 1858) & DEPRJ 8315 \\
\hline \multicolumn{2}{|l|}{ Curimatidae } \\
\hline Curimata vittata (Kner, 1858) & DEPRJ 8389 \\
\hline Curimata roseni Vari, 1989 & DEPRJ 8325 \\
\hline Curimata ocellata Eigenmann \& Eigenmann, 1889 & DEPRJ 8333 \\
\hline Cyphocharax abramoides (Kner, 1858) & DEPRJ 8405 \\
\hline Cyphocharax festivus Vari, 1992 & DEPRJ 8406 \\
\hline \multicolumn{2}{|l|}{ Ctenoluciidae } \\
\hline Boulengerella cuvieri (Cuvier, 1816) & DEPRJ 8403 \\
\hline Boulengerella lucius (Valenciennes, 1850) & DEPRJ 8404 \\
\hline \multicolumn{2}{|l|}{ Triportheidae } \\
\hline Agoniates halecinus Müller \& Troschel, 1845 & DEPRJ 8382 \\
\hline Triportheus albus Cope, 1872 & DEPRJ 8420 \\
\hline \multicolumn{2}{|l|}{ Iguanodectidae } \\
\hline Bryconops alburnoides Kner, 1858 & DEPRJ 8375 \\
\hline \multicolumn{2}{|l|}{ Acestrorhynchidae } \\
\hline Acestrorhynchus falcirostris (Cuvier, 1819) & DEPRJ 8373 \\
\hline Acestrorhynchus microlepis (Jardine, 1841) & DEPRJ 8374 \\
\hline \multicolumn{2}{|l|}{ Siluriformes } \\
\hline \multicolumn{2}{|l|}{ Auchenipteridae } \\
\hline Ageneiosus ucayalensis Castelnau, 1855 & DEPRJ 8400 \\
\hline Auchenipterichthys longimanus (Günther, 1864) & DEPRJ 8398 \\
\hline Auchenipterus nuchalis (Spix \& Agassiz, 1829) & DEPRJ 8402 \\
\hline
\end{tabular}




\begin{tabular}{ll}
\hline Order/Family/Species & Voucher number \\
\hline Siluriformes & \\
Doradidae & DEPRJ 8401 \\
$\quad$ Astrodoras asterifrons (Kner, 1853) & DEPRJ 8377 \\
Hassar orestis (Steindachner, 1875) & DEPRJ 8419 \\
Trachydoras brevis (Kner, 1853) & \\
Loricariidae & DEPRJ 8410 \\
Hypoptopoma elongatum Aquino \& Schaefer, 2010 & DEPRJ 8379 \\
Loricariichthys acutus (Valenciennes, 1840) & \\
Pimelodidae & DEPRJ 8408 \\
Hypophthalmus edentatus Spix \& Agassiz, 1829 & DEPRJ 8409 \\
Hypophthalmus marginatus Valenciennes, 1840 & DEPRJ 8418 \\
Pinirampus pirinampu (Spix \& Agassiz, 1829) & \\
Perciformes & \\
Cichlidae & DEPRJ 8320 \\
Cichla vazzoleri Kullander \& Ferreira, 2006 & DEPRJ 8322 \\
Geophagus altifrons Heckel, 1840 & \\
Sciaenidae & DEPRJ 8321 \\
Plagioscion montei Soares \& Casatti, 2000 & DEPRJ 8327 \\
Plagioscion squamosissimus (Castelnau, 1855) & \\
Clupeiformes & \\
Engraulidae & DEPRJ 8332 \\
Lycengraulis batesii (Günther, 1868) & \\
Pristigasteridae & DEPRJ 8411 \\
Ilisha amazonica (Miranda-Ribeiro, 1920) & DEPRJ 8416 \\
Pellona castelnaeana Valenciennes, 1847 & DEPRJ 8417 \\
Pellona flavipinnis (Valenciennes, 1837) & \\
\hline
\end{tabular}

